\title{
Home pelvic floor muscle training with electromyographic biofeedback to treatment of the urinary incontinence: Short term results. A prospective analysis
}

\author{
Üriner inkontinans tedavisinde pelvik taban egzersizleri \\ nöromodülasyon-biofeedback için evde egzersiz eğitim uygulaması \\ kısa dönem sonuçları
}

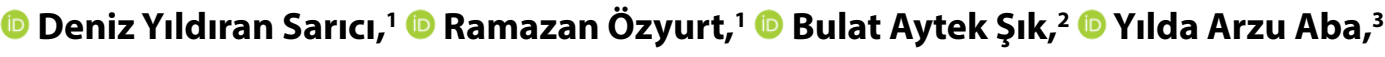 \\ 'Department of Obstetrics and Gynecology, İstanbul Training and Research Hospital, İstanbul, Turkey \\ ${ }^{2}$ Department of Obstetrics and Gynecology, İstanbul Aydın University, İstanbul, Turkey \\ ${ }^{3}$ Department of Nursing, Bandırma Onyedi Eylül University Health Science Faculty, Balıkesir, Turkey
}

\begin{abstract}
Introduction: Pelvic floor muscle training is an accepted therapy to improve or cure symptoms of urinary incontinence. In this study, examination of short term changes in home treatment of pelvic floor muscle training with Femiscan Home Trainer in treatment of urinary incontinence was aimed.

Methods: Prospective analysis in a tertiary-level center. 30 female patients admitted to urogynecology polyclinic with complaints of urinary incontinence $(\mathrm{UI})$ who were given FemiScan biofeedback device for home exercise treatment were included in our study. Patients who could apply home exercise training continuously were included in the study. Detailed anamnesis form, pelvic floor force examination findings, urodynamic examination records and incontinence forms they filled were examined. Muscle force results, urodynamic values and incontinence forms of patients at the end of third month were compared to initial values.

Results: While evaluating results of pelvic floor muscle exercise with biofeedback performed using FemiScan, Electromyography (EMG) amplitude difference, Bladder fullness (BF), Vesical pressure (VP) and BF/VP difference were taken as objective criteria. In the result of statistical analysis of these data, statistically significant increase was observed in EMG amplitude $(\mathrm{P}<0.0001)$, BF values $(P<0.0001)$ and $B F / V P$ ratio after the treatment $(P<0.01)$. No significant change was recorded in VP after the treatment. Number of urinations and amount of urine leaked decreased and statistically significant recovery in ability to stop urine flow were observed.

Discussion and Conclusion: Our study shows that FemiScan (Mega Electronics Ltd, Finland) might be an effective method in UI treatment. Keywords: Nocturia; overactive bladder; urinary incontinence.
\end{abstract}

Özet

Amaç: Bu çalışmada amacımız üriner inkontinans tedavisinde FemiScan Home Trainer (Mega Electronics Ltd., Finlandiya) ile evde pelvik taban kas egzersiz tedavisinin kısa dönem değişikliklerin incelenmesi amaçlanmıştır.

Gereç ve Yöntem: Çalışmamıza ürojinekoloji polikliniğine üriner inkontinans(Üi) şikayetiyle başvuran ve inkontinansı objektif olarak gösterilebilen, tedavide evde egzersiz eğitimi için FemiScan biofeedback cihazı verilmiş olan 30 kadın hasta dahil edilmiş olup bu hastaların dosyaları retrospektif olarak taranmıştır. Evde egzersiz eğitimini kesintisiz olarak uygulayabilmiş olan hastalar çalışmaya dahil edilmiştir. Ayrıntılı anamnez formu, pelvik taban kuvvet muayenesi bulguları, ürodinamik inceleme kayıtları, doldurmuş oldukları inkontinans anketleri incelenmiştir. Hastaların, üçüncü ay sonundaki kas gücü sonuçları, ürodinami değerleri ve inkontinans anketleri başlangıç değerleri ile karşılaştırılmıştır.

Bulgular: FemiScan ile yapılan biofeedback ile pelvik taban kas egzersizi sonuçlarını değerlendirken objeftif kriter olarak EMG amplitüd farkı, MD, VB ve MD/VB farkı dikkate alınmıştır. Bu verilerin istatistiksel analizi sonucu EMG amplitüdünde $(p<0,0001)$, MD değerlerinde $(p<$ 0,0001 ) ve $M D / V B$ oranında da tedavi sonrasında istatistiksel olarak anlamlı olacak şekilde bir artış gözlenmiş̧ir $(p<0,01)$. VB'da ise tedavi sonrasında anlamlı bir değişiklik izlenmemiştir. Tedavi sonrası hastaların idrara çıkma sayısında ve bir seferde kaçırılan idrar miktarında azalma, idrar akışını durdurabilme yeteneğinde istatistiksel olarak anlamlı bir iyileşme izlenmiştir.

Sonuç: Çalışmamız FemiScan (Mega Electronics Ltd., Finlandiya)"nin Üi tedavisinde etkin bir yöntem olabileceğini göstermektedir. Anahtar Sözcükler: Noktüri; overaktif mesane; üriner inkontinans. 
U rinary incontinence $(\mathrm{UI})$ is a condition of involuntary leakage of urine objectively that poses a problem socially or hygienically according to definition of International Continence Organization. ${ }^{[1]}$ Factors like age, parity, obesity, smoking, chronic coughing, constipation, prolapsus and menopause play role in development of urinary incontinence. The most common type of urinary incontinence in women is stress urinary incontinence which is described as involuntary leakage of urine during activities such as coughing, sneezing and holding weight. This is followed by detrusor instability (overactive bladder) characterized by involuntary contractions of detrusor muscle and observed together with symptoms pollakiuria, urgency and nocturia. ${ }^{[2,3]}$ Urinary incontinence affects almost $4.8 \%-58 \%$ of women ${ }^{[4]}$ Lower urinary system dysfunction behavior treatments prominent after assertion of exercise of pelvic floor muscles in treatment of urinary incontinence is separated as ones aiming bladder, like bladder training and behavior modifications and ones aiming bladder output, like pelvic floor muscle exercises, electric stimulation and vaginal axis. Recovery rates of $78 \%-90 \%$ by combined exercise methods with biofeedback are reported in the literature. ${ }^{[5]}$

In this study, examination of short term changes that Femi Scan Home Trainer affected urodynamic parameters of patients treated for urinary incontinence was aimed.

\section{Materials and Method}

\section{Study design, setting and participants}

This prospective study was conducted from January through September 2014 at the outpatient clinics of our institution. Our study included 30 patients those presented to urogynecology polyclinic of Obstetrics and Gynecology Department of Istanbul Training and Research Hospital with complaint of urinary incontinence and with objective incontinence that were given FemiScan biofeedback device for home exercise training. The study was approved by the local ethics committee (date: October 06, 2013; approval number: 263). Files of all patients were analyzed and detailed anamnesis form, general physical examination findings, pelvic floor muscular force examination findings, pelvic floor neurological examination findings, Pelvic Organ Prolapse Quantification System (POP-Q) examination, Q-type examination results, 1 hour pad test results, ultrasound and urodynamic analysis records, 3 days' bladder diary results were evaluated. Patients were evaluated with regard to age groups, parities, body mass indexes (BMI), whether they are in menopause or not, whether they take hormone replacement treatment or not. Additionally, urological and psychosocial recovery level of the patient was analyzed with "incontinence diagnosis questions" prepared by urogynecology unit of our clinic questioning incontinence levels of patients before and after the treatment and its effects to social life.

Blood biochemistry, complete urinary analysis, urinary culture results of all patients were examined. Residual urine amount of patients was examined with the help of $16 \mathrm{Fr}$ Timann catheter. Patients who have a neurological disease that may
Table 1. Demographic and obstetric history characteristics of patients

\begin{tabular}{lcccc}
\hline & $\mathbf{n}$ & Min. & Max. & Mean \pm SD \\
\hline Gravida & 30 & 1 & 17 & $46.0 \pm 5.67$ \\
Partus & 30 & 1 & 8 & $3.17 \pm 1.74$ \\
Abortus & 30 & 0 & 3 & $0.47 \pm 0.82$ \\
Curettage & 30 & 0 & 15 & $1.70 \pm 2.89$ \\
Age (years) & 30 & 31 & 54 & $46.37 \pm 5.67$ \\
Weight $(\mathrm{kg})$ & 30 & 50 & 106 & $71.38 \pm 13.31$ \\
Height $(\mathrm{cm})$ & 30 & 150 & 176 & $158.87 \pm 5.60$ \\
BMI (kg/m $\left.{ }^{2}\right)$ & 30 & 19.778 & 39.896 & $28.29 \pm 5.09$ \\
Duration of & & & & \\
complaint (month) & 30 & 1 & 27 & $5.18 \pm 5.47$ \\
\hline
\end{tabular}

SD: Standard deviation; BMI: Body mass index; Min: Minimum; Max: Maximum.

affect bladder function, patients with recurrent urinary tract infection history, patients with diabetes, patients with pelvic mass that may press over bladder and patients with pelvic relaxations like cystocele, rectocele or descensus uteri and patients with intrinsic sphincter deficiency were excluded in the study. Patients who could apply home exercise training continuously were included in the study. Muscular force results, urodynamic values and incontinence forms of patients at the end of third month were compared to initial values.

\section{Statistical Analysis}

In this study, statistical analyses were carried out by NCSS 2007 package program. Paired t-test was used for evaluation before and after the treatment, Mc Nemar's test was used for comparisons before and after the treatment together with defining statistical methods (mean, standard deviation) for evaluation of data. Mann Whitney $\mathrm{U}$ test with clinical variables was used for Bladder fullness/Vesical pressure (BF/VP) gap and Electromyography (EMG) amplitude gap comparisons. Results were evaluated at significance level of $\mathrm{P}<0.05$.

\section{Results}

Mean age of 30 patients included in the study was $43.37 \pm 5.67$ (31-54). Mean body weight of them was $71.38 \pm 13.31 \mathrm{~kg}(50-$ 106) while their mean BMI value was $28.29 \pm 5.09$ (19.78-39.90) $\mathrm{kg} / \mathrm{m} 2$. Mean duration of patient complaints was $5.18 \pm 5.47$ (1-27) months. Mean gravida number of cases was $5.33 \pm 3.82$ (1-17). Mean birth number of patients was $3.17 \pm 1.74(1-8)$. Mean number of abortions was $0.47 \pm 0.82(0-3)$. Mean curettage number of them was $1.70 \pm 2.89(0-15)$ (Table 1$)$.

Number of patients with stress incontinence which is 19 made the highest percentage of $65.5 \%, 6$ of patients had mixed type and 5 of them had urge incontinence type (Table 2).

While evaluating pelvic floor muscular exercise with biofeedback performed by FemiScan, EMG amplitude gap, BF, VP and $\mathrm{BF} / \mathrm{VP}$ gap were taken as objective criteria.

Urodynamic and muscle force values before the treatment 


\section{Table 2. Types of incontinence}

\begin{tabular}{lcc} 
Types of Incontinence & $\mathbf{n}$ & $\%$ \\
\hline Urge incontinence & 5 & 16.6 \\
Stress incontinence & 19 & 63.4 \\
Mixed incontinence & 6 & 20 \\
Total & 30 & 100 \\
\hline
\end{tabular}

were detected as minimum value of 1.8 , maximum value of 25.8 and mean value of $11.4+6.38$ in EMG, bladder fullness had minimum value of 80 , maximum value of 356 and mean value of $189.08+80$, vesical pressure had minimum value of 32 , maximum value of 197 and mean value of 113 . After the treatment, EMG had minimum value of 5.8, maximum value of 34.3 and mean value of 20.18 , bladder fullness had minimum value of 135, maximum value of 474 and mean value of 311 , vesical pressure had minimum value of 95 , maximum value of 172 and mean value of 122 .

Statistically very significant increase was observed in EMG amplitude after the treatment as a result of statistical anal$y$ sis of these data $(P<0.0001)$. Also, statistically very significant increase was observed in $\mathrm{BF}$ values after the treatment $(P<0.0001)$ and $B F / V P$ ratio after the treatment $(p>0.01)$. No significant change was seen in VP after the treatment (Table 3 ).

20 of patients $(66.7 \%)$ were in menopause. Number of patients who had vaginal surgery was $9(30 \%)$. Number of patients who gave birth to a baby with birth weight of 3500 and over was 14 (46.7\%). While constipation was present in 53.3\% of patients, chronic obstructive pulmonary disease (COPD) was present in $26.7 \%$ of patients. Statistical significance was analyzed between EMG amplitude gap and BF/VP ratio and gynecological, obstetric and systemic histories of patients including menopause, constipation, COPD, birth weight, vaginal operation to research prediction of factors that may affect success after the treatment. As a result of this, statistically significant difference was not observed between BMI, Menopause $(-)$ and $(+)$ groups, COPD (-) and (+) groups, constipation (-) and (+) groups, vaginal operation (-) and (+) groups, $\leq 3500 \mathrm{gr}$ and $>3500$ gr groups, BF/VP recovery gap and EMG amplitude recovery gap (Table 4 ).

Urological and psychosocial recovery levels of the patient were examined with "incontinence diagnosis questions" that reveals continence levels of patients before and after the treatment and its effects to social life. Statistically significant decrease was observed in daily urination number before and after the treatment according to result of the form $(P<0.03)$. Statistically significant decrease was observed in the amount of urine leaked at once after the treatment $(P<0.0001)$. Statistically significant increase was observed also in the ability to stop urination after the treatment $(P<0.005)$. Statistically significant decrease was observed in frequence of incontinence with mild or sudden and heavy exercise after the treatment (respectively $\mathrm{P}<0,017$ and $\mathrm{P}<0.047$ ). Statistically significant decrease was observed also in difficulty in work related duty $(P<0.026)$. Statistically significant decrease was observed in need to stop daily activities like exercise, friend and family visit, going to theatre and shopping $(P<0.001)$. Statistically significant decrease was observed in ratio of effecting sexual life after the treatment $(P<0.032)$ (Table 5).

\section{Discussion}

$\mathrm{Ul}$ is an important symptom that effects physical, psychological, social and economic health of a woman and its prevalence varies between $15 \%-52 \%$ among women. ${ }^{[6]}$ In a study performed in China that included 20000 women with ages between 20 and 99, prevalence of UI was found to be $30.9 \%{ }^{[7]}$ Currently, different treatment approaches are present for a patient with incontinence such as behavior, drug or surgery based treatments. These options are chosen according to risk and potential to fix complaint of the patient. It is recommended to choose the least invasive and least dangerous method as first option. ${ }^{[8]}$

Pelvic floor muscular training is an important physiotherapy and rehabilitation approach in women with POP When the studies on this subject are reviewed it is observed that the exercises for strengthening of pelvic floor muscles are given as home-based exercise programs. ${ }^{[9-11]}$ In the literature, it has been reported that the stabilization exercises are effective on the pelvic floor strength of healthy individuals and other diseased groups. ${ }^{[12]}$ Combined studied with biofeedback treatment in addition to pelvic floor muscular exercises are prominent in lower urinary system dysfunction behavior treatments preferred after suggestion of pelvic floor muscular exercise by Arnold Kegel in 1948 in treatment of urinary incontinence.

In our study, neuromodulation with biofeedback method using FemiScan (Mega Electronics Ltd., Finland) was aimed in our patients with urinary incontinence. Different findings are

Table 3. Comparison of muscular force and urodynamic values before and after the treatment



EMG: Electromyography; BF: Bladder fullness; VP: Vesical pressure; BF/VP: Bladder fullness/Vesical pressure; SD: Standart deviation; $t=t$ testi. 
Table 4. Menopause, vaginal operation, COPD, birth weight, constipation and BF/VP ratio recovery gap, EMG amplitude recovery gap

\begin{tabular}{|c|c|c|c|}
\hline & Menopause (-) & Menopause (+) & $P$ value \\
\hline & $n=10$ & $\mathrm{n}=\mathbf{2 0}$ & \\
\hline $\mathrm{BF} / \mathrm{VP}$ ratio & $0.45 \pm 1.74$ & $0.79 \pm 0.73$ & 0.998 \\
\hline \multirow[t]{3}{*}{ EMG Amplitude gap } & $9.65 \pm 5.35$ & $8.89 \pm 7.03$ & 0.523 \\
\hline & Vaginal operation (-) & Vaginal operation (+) & P value \\
\hline & $n=21$ & $n=9$ & \\
\hline $\mathrm{BF} / \mathrm{VP}$ ratio & $0.61 \pm 1.27$ & $0.53 \pm 0.34$ & 0.358 \\
\hline \multirow[t]{2}{*}{ EMG Amplitude gap } & $9.2 \pm 6.5$ & $10.03 \pm 7.82$ & 0.999 \\
\hline & $\begin{array}{l}\text { Birth weight } \leq 3500 \mathrm{gr} \\
\mathrm{n}=16\end{array}$ & $\begin{array}{c}\text { Birth weight }>3500 \mathrm{gr} \\
\mathrm{n}=14\end{array}$ & $P$ value \\
\hline $\mathrm{BF} / \mathrm{VP}$ ratio & $0.9 \pm 0.46$ & $0.36 \pm 1.52$ & 0.412 \\
\hline \multirow[t]{3}{*}{ EMG Amplitude gap } & $8.88 \pm 7.62$ & $9.72 \pm 5.29$ & 0.407 \\
\hline & COPD (-) & COPD (+) & $P$ value \\
\hline & $n=22$ & $n=8$ & \\
\hline BF/VP ratio & $0.82 \pm 0.5$ & $0.02 \pm 2.1$ & 0.586 \\
\hline \multirow[t]{3}{*}{ EMG Amplitude gap } & $9.94 \pm 6.17$ & $7.58 \pm 7.45$ & 0.305 \\
\hline & Constipation (-) & Constipation (+) & $P$ value \\
\hline & $n=14$ & $n=16$ & \\
\hline BF/VP ratio & $0.8 \pm 0.58$ & $0.39 \pm 1.62$ & 0.913 \\
\hline \multirow[t]{3}{*}{ EMG Amplitude gap } & $10.26 \pm 5.84$ & $8.49 \pm 7.07$ & 0.335 \\
\hline & $\mathrm{BMI}<30$ & $\mathrm{BMI}>\mathbf{3 0}$ & $P$ value \\
\hline & $\mathbf{n = 2 1}$ & $n=9$ & \\
\hline BF/VP ratio & $0.72 \pm 0,66$ & $0.53 \pm 2.02$ & 0.405 \\
\hline EMG Amplitude gap & $9.2 \pm 6.29$ & $8.98 \pm 7.25$ & 0.851 \\
\hline
\end{tabular}

EMG: Electromyography; BF: Bladder fullness; VP: Vesical pressure; BF/VP: Bladder fullness/Vesical pressure.

present in literature about effect of age in biofeedback treatment. Rett et al. performed a study over women in reproductive age and reported that life quality, pelvic floor muscular strength and EMG measurements improved after biofeedback pelvic floor exercise treatment. ${ }^{[13]}$ Also Tadic et al. showed in a study that they performed on patients older than 60 years that sense of well-being significantly increased not only psychologically but also urinary incontinence in patients after the biofeedback treatment. ${ }^{[14]}$ Henderson et al. performed a study and reported $80 \%$ success rate in patients under 55 years of age that were exercised with combined Kegel exercise together with biofeedback and $67 \%$ success rate in patient group over 55 years of age. ${ }^{[15]}$ As seen in these studies, satisfactory results may be achieved in all age groups by treatment performed with biofeedback. Mean age group was 55 in our study and statistically significant recovery was observed in urodynamic values, EMG values and psycho-social life quality after the treatment.

Body/Mass index (BMI) is accepted to be a risk factor for urinary incontinence. But it was stated that there was no direct relationship between $\mathrm{BMI}$ and urodynamic parameters despite high BMI. ${ }^{[16]}$ In our study, BMI of our patients were between 19,778 and 39,896 and their mean was 28,295 . Statistically significant difference was not observed in MF/VP ration recovery gap $(P=0.405)$ and $E M G$ amplitude recovery gaps before and after the treatment in patient group which were classified as $\mathrm{BMI} \leq 30$ and $\mathrm{BMI}>30(\mathrm{P}=0.851)$.

Studies showed that $\mathrm{UI}$ increases after entering menopause period. ${ }^{[17]}$ Demirci et al. 18 report that $56.4 \%$ of women in postmenopausal period somehow describes incontinence and Luna et al. also similarly report that $\mathrm{UI}$ is seen more in postmenopausal period. ${ }^{[17,18]}$ When we analyzed the effect of presence of menopause on treatment success, ratio of our patient in menopause was $66.7 \%$ while ratio of patients not in menopause was $33.3 \%$. Statistically significant difference was not observed in BF/VP ratio recovery gap of Menopause $(-)$ and $(+)$ groups and in EMG amplitude recovery gaps ( $\mathrm{P}=0.998, \mathrm{P}=0.523$ ).

While significant relation was present between $\mathrm{UI}$ and delivery of large baby in some studies, significant relation was not found in some studies. ${ }^{[19,20]}$ Statistically significant difference was not observed in BF/VP ratio recovery gap and EMG amplitude recovery gap between groups delivering children with birth weights $\leq 3500 \mathrm{gr}$ and $>3500 \mathrm{gr}$ (respectively $\mathrm{P}=0.412, \mathrm{P}=0.407$ ).

Secondly, we analyzed possible relation of situations that may lead to intraabdominal pressure changes that is important especially in stress urinary incontinence (SUI) with treatment 


\section{Table 5. Effects of urinary incontinence on daily and social life before and after the treatment}

\section{Effects of urinary incontinence on daily and social life}

\section{Before treatment}

Daily urination frequency

\section{5-7 times}

10 times

$>10$ times

Frequency of urination at night

$$
\begin{aligned}
& \text { 0-1 times } \\
& \text { 2-3 times }
\end{aligned}
$$$$
>4 \text { times }
$$

Residual urine feeling

No

Often

Sometimes

Urgency to urination feeling with excitement

No

Severe

A little

Leaking of urine with forcing

It's different

Yes

Sometimes

Leaking of urine during intercourse

After forcing

Yes

I can't tell

Urgency feeling

No

Often

Sometimes

How much urine is leaking?

Drop

A little

Starts to flow

Stopping urine flow

A little

Quite good

No

Independent urine leaking (without forcing)

No

Sometimes

Often

Urine leaking with mild forcing

No

Sometimes

Often

Urinary Incontinence with quick and increased physical activity

None of the time

rarely

Often n

$\%$

56.7

16.6

26.7

8

21

3

6

19

3

8

15

12

3

3

25

2

9

17

4

4

12

12

6

6

6
18

18
6

15

11

4

18

9

3

3

8

16

6

4

15

11

\section{After treatment}

p

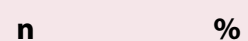

0.03

70.0

30

0

0.103

76.6

23.4

0

0.245

76.7

10

13.3

0.691

76.7

0

23.3

0.626

26.6

46.7

26.6

0.869

46.7

30

23.3

0.246

66.7

13.3

20

0.0001

70

23.3

6.7

0.005

3.3

96.7

0

0.283

80

6.7

13.3

0.017

73.3

0

26.7

8

0.047
40

33.3

26.7 
Table 5 (cont.). Effects of urinary incontinence on daily and social life before and after the treatment

\begin{tabular}{|c|c|c|c|c|c|}
\hline \multirow[t]{2}{*}{ Effects of urinary incontinence on daily and social life } & \multicolumn{2}{|c|}{ Before treatment } & \multicolumn{2}{|c|}{ After treatment } & \multirow[t]{2}{*}{$\mathbf{p}$} \\
\hline & $\mathbf{n}$ & $\%$ & $\mathbf{n}$ & $\%$ & \\
\hline Difficulty in performing everyday activities & & & & & 0.204 \\
\hline None of the time & 11 & 36.7 & 19 & 63.3 & \\
\hline Sometimes & 10 & 33.3 & 2 & 6.7 & \\
\hline Often & 9 & 30 & 9 & 30 & \\
\hline Bothering at work & & & & & 0.026 \\
\hline None of the time & 8 & 26.7 & 22 & 73.3 & \\
\hline Sometimes & 13 & 43.3 & 2 & 6.7 & \\
\hline Often & 9 & 30 & 6 & 20 & \\
\hline Fear of urine leakage in public & & & & & 0.305 \\
\hline None of the time & 6 & 20 & 16 & 53.3 & \\
\hline Sometimes & 12 & 40 & 3 & 10 & \\
\hline Often & 12 & 40 & 11 & 36.7 & \\
\hline Need of quitting current activity & & & & & 0.001 \\
\hline None of the time & 10 & 33.2 & 24 & 80 & \\
\hline Sometimes & 5 & 16.7 & 0 & 0 & \\
\hline Often & 15 & 50 & 6 & 20 & \\
\hline Negative effect on sexual activity & & & & & 0.032 \\
\hline None of the time & 8 & 26.7 & 17 & 56.7 & \\
\hline Sometimes & 7 & 23.3 & 4 & 13.3 & \\
\hline Often & 15 & 50 & 9 & 30 & \\
\hline Genital rash & & & & & 0.062 \\
\hline None of the time & 6 & 20 & 18 & 60 & \\
\hline Sometimes & 19 & 63.3 & 8 & 26.7 & \\
\hline Often & 5 & 16.7 & 4 & 13.3 & \\
\hline Wearing diaper/pad & & & & & 0.0001 \\
\hline None of the time & 0 & 0 & 16 & 53.3 & \\
\hline Sometimes & 28 & 93.3 & 13 & 43.4 & \\
\hline Often & 2 & 6.7 & 1 & 3.3 & \\
\hline
\end{tabular}

results. It is stated that constipation does damage by causing tension in pelvic nerves and this may affect pelvic floor functions negatively. It was identified in studies that women with SUI and prolapses slog on during defecation. ${ }^{[21]}$

Statistically significant difference was not observed in BF/ VP ratio recovery gap and EMG amplitude recovery gap between constipation (-) and (+) groups (respectively $\mathrm{P}=0.913$, $P=0.335$ ). Also statistically significant difference was not observed in BF/VP ratio recovery gap and EMG amplitude recovery gap between COPD (-) and (+) groups (respectively $\mathrm{P}=0.586, \mathrm{P}=0.305$ ).

These results show us that parameters accepted to be a risk factor for UI do not have effect on PFME performed with biofeedback.

Thirdly, urological and psychosocial recovery level of the patient was analyzed by "Incontinence diagnosis questions" prepared by our urogynecology unit of our department questioning incontinence levels of patients before and after the treatment and its effects to social life. Accordingly; while $20 \%$ of patients gave "starts to flow" answer that was the worst level to the question "How much urine do you leak at once?" before the treatment, this regressed to $6.7 \%$ level after the treatment. Also, "small amount" answer was $60 \%$ before the treatment but it regressed to $23.3 \%$ after the treatment. These results were found to be statistically very significant $(\mathrm{P}=0.0001)$. Also, "ability to stop urination" that is one of the most important parameters came to "quite good" level which is the highest level between answers "yes", "no", "quite good" and this result was found to be statistically significant $(P=0.005)$. Based on decrease in daily urination frequency, regression of urinary incontinence to "drop by drop and small amount" level and being of ability to stop urination at "quite good" level with $96.7 \%$ ratio, we can say that our results of biofeedback neuromodulation performed by FemiScan are pretty successful.

While "No" answer to the question "Do you leak urine with a mild forcing? (for example: while standing up, walking)" was in $26.7 \%$ level before the treatment, this answer came to $73.3 \%$ level after the treatment. Also, while "sometimes" answer to this question was $53.3 \%$ before the treatment, it regressed to 
$0 \%$ after the treatment and these results were found to be statistically significant $(\mathrm{P}=0.017)$. While "NO" answer to the question "Do you leak urine with sudden and heavy forcing (for example: while sneezing, coughing or running)" that is especially important in stress incontinence was $13.3 \%$, it became $40 \%$ after the treatment and while "sometimes" answer was 50\% before the treatment, it regressed to $33.3 \%$ after the treatment and was found to be statistically significant $(P=0.047)$. While "no" answer to "Do symptoms leave you in the lurch at work?" in evaluations about social life was $25.6 \%$ before treatment, it came to $75 \%$ after the treatment. Also, "sometimes" answer regressed to $3.6 \%$ from $42.9 \%$ after the treatment and results were found to be statistically significant $(\mathrm{P}=0.026)$. "Often" answer given to questions like "Do you stay obliged to stop daily activities like exercise, friend or relative visit, going to theatre or shopping?" regressed to $20 \%$ from $50 \%$ after the treatment. "NO" answer progressed to $80 \%$ from $33.3 \%$ and this result was found to be statistically significant $(P=0.001)$. Another important problem in these patients is its negative effects to sexual life. "OFTEN" answer to the question in this direction that was $50 \%$ before the treatment regressed to $30 \%$ after the treatment and this result was found to be statistically significant $(\mathrm{P}=0.032)$. While patients gave "NO" answer to "Do you stay obliged to use a swab or a pad?" at 0 level, this ration came to $53.3 \%$ after the treatment and this result was found to be statistically very significant $(P=0.0001)$. We considered $E M G$ values and urodynamic parameters like $\mathrm{BF}, \mathrm{VP}, \mathrm{BF} / \mathrm{VP}$ for evaluation of success of treatment objectively in our study. According to this: EMG (amplitude) mean values were found statistically significantly higher than values before treatment $(P=0.0001)$. BF mean values after the treatment were found statistically significantly higher than values before treatment $(P=0.0001)$. Statistically significant difference was not observed in VP mean values before and after the treatment $(P=0.181)$. BF/VP mean values after the treatment were found statistically significantly higher than values before treatment $(P=0.01)$.

Conservative approaches to urinary incontinence become prominent gradually. Aim in the treatment of this disease is to use least invasive one with least side effects. Position of PFME in treatment that may be characterized as behavioral treatment is revealed with studies carried out in last years. Dumolin $\mathrm{C}$ and Hay-Smith J compared PFME application in women to patients who did not receive any treatments in a compilation study they performed and they recommend PFME to be first step treatment for stress, urge and mixed incontinence as a result of literature scans. ${ }^{[22]}$

Despite report of good results in UI treatment done by PFME, researchers made effort for making this training more effective by biofeedback. This topic is expressed in studies performing combined exercise methods by biofeedback in the literature. Berghmans LC et al. carried out a study questioning if PFME combined with biofeedback (BF) (group 1) gives better result than treatment with only PFME (group 2) or not. They grouped 40 patients as group 1 and group 2 randomly. Every patient received treatment for 12 weeks three times a week. Success- ful result was obtained in both groups at the end of $12^{\text {th }}$ week. But this result was reached at the end $6^{\text {th }}$ week in biofeedback group, author states that treatments with $\mathrm{BF}$ addition might be more effective. ${ }^{[23]}$

Quite successful results are obtained in the last years with EMG-helped PFME treatments done at home. Aukee et al. gave EMG-helped BF device for exercising at home to some of 30 voluntary patients between ages 31 and 69 and some of them were exercised without BF. They recommended them to exercise 5 times in a week for 20 minutes in each for 12 weeks. As a result of the study, they recommend that EMG-helped BF training is more helpful than only PFME. After these early results, same researchers compared 1 year follow results in the same patient groups. At the end of 1 year, they reported that success was achieved in 11 (68.8\%) of 16 patients in the group that were trained with $\mathrm{BF}^{[24]}$

\section{Conclusions}

In the result of our study, it is seen that biofeedback neuromodulation performed by FemiScan (Mega Electronics Ltd. Finland) has quite satisfactory results in treatment of UI. In conditions that disturb people in work life and social life and prevent people from doing their job and sometimes cause them to stop, we see that this treatment provides a significant recovery in a level that relaxes people and with statistical significance. Additionally, almost two times increase is observed in pelvic muscular contractions in measurements done by EMG. Our study shows that FemiScan (Mega Electronics Ltd. Finland) might be an effective method in the treatment of UI.

Conflict of interest: There are no relevant conflicts of interest to disclose.

\section{References}

1. Abrams $\mathrm{P}$, Cardozo L, Fall M, et al. The standardisation of terminology of lower urinary tract function: Report from the standardisation sub-committee of the international Continence Society. Urology. 2003;61(1):37-49. PMID: 12559262; doi: 10.1002/nau.10052.

2. Anders K. Recent developments in stress urinary incontinence in women. Nurs Stand. 2009;Suppl:25-7, 29-32. PMID: 20085018; doi: 10.7748/ns2006.05.20.35.48.c4147.

3. Stewart WF, Van Rooyen JB, Cundiff GW, et al. Prevalence and burden of overactive bladder in the United States. World J Urol. 2003;20(6):327-36. PMID: 12811491; doi: 10.1186/1471-2296-108.

4. Minassian VA, Drutz HP, Al-Badr A. Urinary incontinence as a worldwide problem. Int J Gynaecol Obstet. 2003;82(3):327-38. PMID: 14499979; doi: 10.1016/S0020-7292Ž03.00220-0.

5. Burns PA, Pranikoff K, Nochajski TH, et al. A comparison of effectiveness of biofeedback and pelvic floor muscle exercise treatment of stress incontinence in older community-dwelling women. J Gerontol. 1993;48(4):M167-74. PMID: 8315230.

6. Yip SK, Cardozo L. Psychological morbidity and female urinary incontinence. Best Pract Res Clin Obstet Gynaecol. 2007;21(2):3219. PMID: 17207664; doi: 10.1016/j.bpobgyn.2006.12.002. 
7. Zhu L, Lang J, Liu C, et al. The epidemiological study of women with urinary incontinence and risk factors for stress urinary incontinence in China. Menopause. 2009;16(4):831-6. PMID: 19240656; doi: 10.1097/gme.0b013e3181967b5d.

8. Fanti JA, Newman DK, Colling J, et al. Urinary incontinence in adults: Acute and chronic management. Clinical practice guideline, 1996 Update. Agency for Health Care Policy and Research. 1996;96(2):154.

9. Hagen S, Stark D, Glazener C, et al. Individualised pelvic floor muscle training in women with pelvic organ prolapse (POPPY): a multicentre randomised controlled trial. Lancet. 2014;383(9919):796806. PMID: 24290404; doi: 10.1016/S0140-6736(13)61977-7.

10. Braekken IH, Majida M, Engh ME, Bø K. Morphological changes after pelvic floor muscle training measured by 3-dimensional ultrasonography: a randomized controlled trial. Obstet Gynecol. 2010;115(2 Pt 1):317-24. PMID: 20093905; doi: 10.1097/ AOG.0b013e3181cbd35f.

11. Stüpp L, Resende AP, Oliveira E, et al. Pelvic floor muscle training for treatment of pelvic organ prolapse: an assessor-blinded randomized controlled trial. Int Urogynecol J. 2011;22(10):1233-9. PMID: 21484362; doi: 10.1007/s00192-011-1428-x.

12. Talasz H, Kalchschmid E, Kofler M, Lechleitner M. Effects of multidimensional pelvic floor muscle training in healthy young women. Arch Gynecol Obstet. 2012;285(3):709-15. PMID: 21837426; doi: 10.1007/ s00404-011-2039-y.

13. Rett MT, Simoes JA, Herrmann V, et al. Management of stress urinary incontinence with surface electromyography-assisted biofeedback in women of reproductive age. Phys Ther. 2007;87(2):136-42. PMID: 17213411; doi: 10.2522/ptj.20050318.

14. Tadic SD, Zdaniuk B, Griffiths D, et al. Effect of biofeedback on psychological burden and symptoms in older women with urge urinary incontinence. J Am Geriatr Soc. 2007;55(12):2010-5. PMID: 18028340 doi: $10.1111 /$ j.1532-5415.2007.01461.x.

15. Henderson JS, Taylor KH. Age as a variable in an exercise program for the treatment of simple urinary stress incontinence. J Obstet Gynecol Neonatal Nurs. 1987;16(4):266-72. PMID: 3650327; doi: 10.1111/j.1552-6909.1987.tb01584.x.

16. Bai SW, Kang JY, Rha KH, et al. Relationship of urodynamic parameters and obesity in women with stress urinary incontinence. J Reprod Med. 2002;47(7):559-63. PMID: 12170533.

17. Luna MT, Hirakawa T, Nakano H. Urinary inkontinance in women seen in the obstetrics and gynecology clinic. Int Urogynecol J Pelvic Flor Dysfunct. 2000;11(5):277-81. PMID: 11052561.

18. Demirci F, Özden S, Yücel N, Yalti S, Demirci E. Prevelance of urinary incontinence in Turkish menopausal women. Turk J Obstet Gynecol. 1999;3(2):138-42.

19. Rogers RG, Leeman LL. Postpartum genitourinary changes. Urol Clin North Am. 2007;34(1):13-21. PMID: 17145356; doi: 10.1016/j. ucl.2006.10.005.

20. Rortveit G, Daltveit AK, Hannestad YS, Hunskaar S. Vaginal delivery parameters and urinary incontinence: The Norwegian EPINCONT study. Am J Obstet Gynecol. 2003;189(5):1268-74. PMID: 14634552; doi:10.1067/S0002-9378(03)00588-X.

21. Cardozo L. New developments in the management of stres urinary incontinence. BJU Int. 2004;94 Suppl 1:1-3. PMID: 15139856; doi: 10.1111/j.1464-410X.2004.04807.x.

22. Dumoulin C, Hay-Smith J. Pelvic floor muscle training versus no treatment for urinary incontinence in women. A Cochrane systematic review. Eur J Phys Rehabil Med. 2008;44(1):47-63. PMID: 18385628. doi: 10.1002/14651858.CD005654.

23. Berghmans LC, Hendriks HJ, De Bie RA, et al. Conservative treatment of urge urinary incontinence in women: a systematic review of randomized clinical trials. BJU Int. 2000;85(3):254-63. PMID: 10671878; doi: 10.1046/j.1464-410x.2000.00434.x.

24. Aukee $P$, Immonen $P$, Penttinen J, Laippala P, Airaksinen O. Increase in pelvic floor muscle activity after 12 weeks' training: a randomized prospective pilot study. Urology. 2002;60(6):1020-3. PMID: 12475661. 